\title{
A review on potato microtuber storability and dormancy
}

\author{
Murlidhar J. Sadawarti ${ }^{1 *}$, K. K. Pandey ${ }^{2}$ B. P. Singh ${ }^{3}$ and R. K. Samadiya ${ }^{1}$ \\ ${ }^{1}$ ICAR-Central Potato Research Station, Gwalior- 474006 (Madhya Pradesh), INDIA \\ ${ }^{2}$ ICAR-Indian Institute of Vegetable Research- Varanasi- 221305 (U.P.), INDIA \\ ${ }^{3}$ ICAR-Central Potato Research Institute, Shimla- 171001 (Himachal Pradesh), INDIA \\ *Corresponding author. E-mail: murlidharsada@gmail.com
}

Received: January 21, 2016; Revised received: August 4, 2016; Accepted: November 6, 2016

\begin{abstract}
Potato microtubers plays important role in seed potato production technology as it has great advantage of storage, transport and mechanization due to their little size and reduced weight. Dormancy in potato microtubers is very important and storage conditions as well as size of microtubers influences the dormancy in microtubers. Increasing size of the micro-tuber resulted in significant increase in the viability and sprouting ability of microtubers with reduced durations of dormancy and weight loss at the end of storage. Small microtubers are more vulnerable to storage damage. The larger microtubers lost moisture content more slowly and retained firmness longer when stored at $4^{\circ} \mathrm{C}$. Development of dormancy during storage strongly affected by the storage condition especially the temperature regime, the presence of light and the relative humidity. The dormancy duration was linearly and inversely correlated with the length of storage. Storage containers and conditions are also important for microtuber storage. Endogenous hormones ABA, ethylene, cyokinin and gibberllic acid play a significant role in tuber dormancy regulation.Microtubers with thick diameter which have passed more times in dormancy and have better functionality than small microtubers with less time in dormancy. Growth regulators like gibberellic acid, thiourea, gibberllic acid + thiourea, randite and carbon disulphide plays significant role in dormancy breaking of microtubers.
\end{abstract}

Keywords: Dormancy, Microtuber, Potato, Seed and storability

\section{INTRODUCTION}

Potato micro-tubers are intermediary phase between "in vitro" plantlets/ microplants and minitubers. Microtubers are developed from tissue culture technology and used for solving the problems of transplanting the plantlets/microplants from "in vitro" to "in vivo" conditions. The microtubers offer a lot of advantages of storage, transport, exchange of a healthy germplasm and mechanization due to their little size and reduced weight (Kefi et al., 2000; Rosu, 2004; Kanwal et al., 2006). They can be planted directly in the light soil of nethouse and greenhouse to produce minitubers as they have similar morphology and biochemical features with traditional tubers.

Storability of microtuber: In vitro microtubers can be alternative propagating materials over microplantsin seed potato programme provided higher tuberization rate and proper storage for longer time without considerable loss (Lazányi et al., 1998). The length of the dormancy depended on size of the microtubers: smaller microtubers had longer dormancy periods than larger microtubers (Leclerc et al., 1995 and Ranalli, 1997). Dormancy of minitubers is usually longer than the dormancy of normal seed tubers due to small size (Lommen, 1994). Sprouting and growth vigour of normal seed tubers also depend on seed tuber size and storage conditions (Burton, 1978; Rastovski and van EsA., 1987; Struik and Wiersema, 1999). Larger sizes gave more vigorous sprouting and higher growth vigour of these sprouts and more weight (Wiersema et al., 1987; Van Ittersum, 1992; Struik and Wiersema, 1999). Small microtubers are more vulnerable to storage damage (Naik and Sarker, 1997).

Storage conditions and containers/ packaging materials have influence on storability of potato microtubers. When three grades $(4,6$ and $8 \mathrm{~mm})$ of microtuber of Kufri Chandramukhi stored for 8 months at $4^{0} \mathrm{C}$ in perforated poly bags and then kept for 3.5 months in plastic petriplates, ventilated culture bottles and perforated plastic bags under ambient conditions, nonhermatic and hermetic culture rooms at Shimla, weight loss was higher in $4 \mathrm{~mm}$ as compared to 6 and $8 \mathrm{~mm}$. Ventilated culture bottles were found to be better container/ storage material than plastic petriplates and perforated plastic bags. In another experiment at CPRI, Shimla when above three grades of microtubers stored for 8 months at $4^{\circ} \mathrm{C}$ in perforated poly bags and then kept for 3 months in 5 different packaging material viz, plastic bag, butter paper, muslin cloth, brown paper and paper box at ambient temperature. The plastic paper bag and butter bag found to be best packaging material with minimum weight loss for all the grades and varieties (Annual Report-CPRI, 2012). 
Microtuber weight loss was higher at room temperature (control) followed by refrigerator and growth chamber at $3^{0} \mathrm{C}$ condition (Fig. 1). As far as storage containers are concern, the weight loss was higher in conical flask with cotton plug and least in polythene without ventilation after 45 days of storage at room temperature (Fig. 2). Among varieties, Kufri Chandramukhi recorded higher weight loss followed by Kufri Lauvkar under Gwalior conditions (Annual ReportCPRS, 2012, Annual Report-CPRI, 2012). This confirms the proper storage containers and conditions are important for minimum weight loss and rottage of microtubers. PWTV- Polythene without ventilation, PWV- Polythene with ventilation, COT PLUG- Conical flask with cotton plug, PLASTIC CAP- Conical flask with plastic cap, PETRI- Petriplates.

Size of microtubers can be used as an index for grading their quality as seed potatoes and size should be at least $0.5 \mathrm{~g}$ to be used as seed potato as larger microtubers lost moisture content more slowly and retained firmness longer when stored at $4^{0} \mathrm{C}$. In the sprouting test also, the larger ones had less period of dormancy and showed more vigorous sprouting ability (Park et al., 2009). Increasing size of the micro-tuber resulted in a significant increase in the viability and sprouting ability of microtubers with reduced durations of dormancy and weight loss at the end of storage when tested for four grades of microtubers (large, medium, small and micro-tubers with burst lenticels) from six Indian potato cultivars and storage regime: of refrigerated $\left(4^{0} \mathrm{C}\right)$ conditions for 3 months followed by 2 -week storage at $22 \pm 2^{\circ} \mathrm{C}$ and 2 -weeks under ambient conditions (about $18^{\circ} \mathrm{C}$ ) (Sharma et al., 2012). Close interactions were recorded between genotype and storage conditions (Van Ittersum and Struik, 1992; Struiket al., 2006 ) and between seed tuber size and storage conditions (Struik and Wiersema, 1999). Usually, the dormant period was shorter in early cultivars than in later cultivars (Harris, 1992), although this relation was not very strict (Burton, 1968).

\section{Percent weight loss}

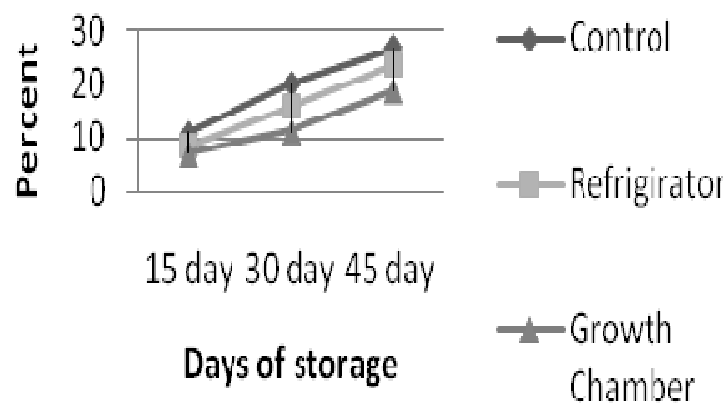

Growth conditions during seed production (especially temperature, photoperiod, light intensity, and nitrogen fertilization) and storage condition especially the temperature regime; the presence of light and the relative humidity have a strong impact on development of dormancy in potato (Van Ittersum and Struik, 1992; Struik and Wiersema, 1999). Among three potato cultivar cv Spunta, P-3, DTO-2 and LT-2 stored at three levels of temperature i.e. $1-5{ }^{\circ} \mathrm{C}$. and at various levels of $\mathrm{CO}_{2}$ concentration showed minimum loss in sprout length and weight except in cv DTO-2, the reduction of sprout length was significant when stored at 30 and $40 \% \mathrm{CO}_{2}$ (Narong, 1988). Sprouting was found to be highly genotype-dependent and was influenced by temperature and storage treatment. Storage in screw -capped bottles with or without $\mathrm{GA}_{3}$ treatment was also found favorable due to ethylene accumulation which can be used for shortening the lag time from harvest to utilization of microtubers for planting (Paet, 1996).

Dormancy in microtubers: Dormancy of a potato tuber is defined as the physiological state in which autonomous sprout growth will not occur, even when the tuber is placed under conditions for sprout growth (Reust, 1986). Pruski et al. (2003) reported that when dormancy of microtubers is not completed, less number of plants is produced. Microtuber dormancy appears to be correlated with field dormancy duration in cultivar specific manner (Leclerc et al., 1995). At harvest, potato tubers are dormant and will not sprout. Endogenous hormones have been posited to plays key role in tuber dormancy regulation. ABA and ethylene are required for dormancy induction but only $\mathrm{ABA}$ is needed to maintain bud dormancy. An increase in cytokinin sensitivity and content plays important role in dormancy exit. Changes in endogenous IAA and GA content are more closely related to the regulation of subsequent sprout growth (Suttle, 2004).

Influence of light intensity and storage conditions on microtuber dormancy: The length of tuber dormancy depends on both the genotype and environ-

Figs. 1and 2 : Weight losses of microtubers in relation to storage conditions and containers. 
mental conditions during growth and storage. Tuber formation under cool and wet conditions may extend the dormant period, whereas hot and dry conditions typically shorten dormancy (Burton, 1989). The effects of light intensities depended on the photoperiodic treatments applied for tuber induction. Lower the light intensity longer the dormant period for cultivars and also the dormancy was long and was greatly elongated by low storage temperature (Tábori et al., 2000). The dormancy duration was linearly and inversely correlated with the length of storage. Dormancy decreased from 28.1 to $19.9,11.1$ and 7.8 days with reduced time of storage when microtubers of 13 cultivars were induced and stored in the dark at $3^{0} \mathrm{C}$ for different periods (28, 56, 84 and 105 days), prior to being transferred to $20^{\circ} \mathrm{C}$ for between 4 and 17 weeks. CvsArsy, Nicola and Jaerla took consistently more time for dormancy release. (Ranalli et al., 1994).

Influence of size of microtubers on dormancy: Size and dormancy of mother microtubers has significant influence on functionality of produced minitubers. Microtubers with thick diameter which have passed more times in dormancy have better functionality than small microtubers with less time in dormancy (Bolandi et al., 2011). After harvest, normal seed tubers show dormancy for about 1-15 weeks, depending on cultivar, tuber size, conditions before harvest and storage conditions. Small tubers, such as minitubers, even have longer periods of dormancy (Lommen, 1993) and are more sensitive to adverse conditions during storage (Struik and Lommen, 1999). Smaller microtubers $(\leq 250 \mathrm{mg}$ ) had longer dormant periods than did those greater than $250 \mathrm{mg}$ with significant difference in sprouting speed (Leclerc, 1995; Struik and Lommen, 1999). Microtubers with $3 \mathrm{~g}$ weight, sprout after 10 days more vigorously with higher sprouting speed than microtubers with 375 and $750 \mathrm{mg}$ (sprout after 15 and 13 days ) when tested for six cultivars (Park et al., 2009). The germination percentage was $84 \%, 86 \%$ and $40 \%$ in $8 \mathrm{~mm}, 6 \mathrm{~mm}$ and $4 \mathrm{~mm}$ grade microtubers respectively after 65 days of storage at ambient conditions in Kufri Lauvkar (Annual Report- CPRI, 2011).

Influence of growth regulators \& chemicals on microtuber dormancy: An endogenous plant hormones abscisic acid, cytokinins, gibberellic acid, and ethylene have been implicated in dormancy regulation (Wiltshire and Cobb, 1996, Suttle, 2004). Dormancy is regulated by the relative concentrations of growth promoters and inhibitors. Gibberellins and cytokines are generally considered to be growth promoters, whereas abscisic acid and ethylene are believed to inhibit sprout growth (Sonnewald, 2001). ABA and ethylene are required for dormancy induction but only ABA is needed to maintain bud dormancy. An increase in cytokinin sensitivity and content is the principal factors for dormancy release. Changes in endogenous IAA and GA content are closely related to the regulation of subse- quent sprout growth (Suttle, 2004).

Dormancy can be removed by setting the store temperature, cutting the tubers, and treating by chemicals. Treating minitubers with chemicals is a safe and confident method. Among the chemicals applied for breaking down the potato nodes dormancy, one can refer to $\mathrm{GA}_{3}$, thiourea, ethylene, ethyl bromide, and carbon disulphide (Otroshy, and Struik, 2006.). On a commercial scale, Rindite, bromoethane, $\mathrm{CS}_{2}, \mathrm{GA}_{3}$ and thiourea have been used to break potato tuber dormancy. Exogenous application of thiourea, offers an economical and safe method to break potato minituber dormancy (Hosseini et al., 2011).

Gibberllic acid: $\mathrm{GA}_{3}$ application efficiently alleviates tubers dormancy (Mosley, 2007). GA 3 application effectively reduced dormancy period and time needed for mini-tubers sprout emergence. However, suitable $\mathrm{GA}_{3}$ concentration for dormancy soothing of potato minitubers need to be standardized (Hassan-Panah et al., 2007 and Khorshidi-Benam and Hassan-Panah, 2008).

The microtubers treated with $\mathrm{GA}_{3}$ took 19 days in cultivar 'Desire', while $\mathrm{GA}_{3}$ and randite took 31 and 21 days respectively to sprout $50 \%$ of the microtubersin cultivars 'Atlantic' and 'Diamont'. The microtubers treated with $\mathrm{GA}_{3}$ produced thin and elongated sprouts (Rehman et al., 2003). GA 3 application as liquid solutions accelerated eyes growth via sprout emergence and produced more slim accessory shoots (Rehman et al., 2003 and Van Hiele, 1961). Soaking of peeled microtubers treated with $0.1-1.0 \mathrm{mg} / \mathrm{l} \mathrm{GA}_{3}, 0.1$ to $1.0 \mathrm{mg} /$ $1 \mathrm{IAA}$ and 0.01 to $0.1 \mathrm{mg} / \mathrm{l} \mathrm{Kinetin}$ for 1 to $25 \mathrm{~min}$ and put on water soaked cotton pad containing in petriplates showed $>90 \%$ sprouting within 7 days while treatment of intact microtuber with $\mathrm{GA}_{3}(0,5$, 10 and $15 \mathrm{mg} / \mathrm{l})$ did not show any significant effect on dormancy breaking (Hossain, 2012). GA 3 application at $160 \mathrm{ppm}$ is the most suitable concentration for dormancy alleviation, acceleration of seedling emergence (Shekari et al., 2010). GA 3 treatment after 2, 3 and 8 week of cold storage of minitubers was found best and most effective dose was $500 \mathrm{mg} / 1 \mathrm{GA}_{3}$ in breakingdormancy and inducing precocious sprouting (Habib, 1999). $\mathrm{GA}_{3} 1500 \mathrm{ppm}$ and 5\% thiourea decreases dormancy period from 63 days to 39 days.(Hassan-Panah et al., 2007). GA 3 @30 ppm application is best suitable for dormancy alleviation (Benedetti, 2005) while, 5 ppm $\mathrm{GA}_{3}$ is appropriate dose for dormancy relief and yield improvement of 'Agria', 'Marfona' and 'Gloria' potatoes (Rehman et al., 2003).

Thiourea: Thiourea is a catalase inhibitor, which triggers potato tubers germination and healing tubers injuries. Thiourea in an appropriate concentrate not only facilitates germination, but also produces more than one sprout in each eyes of potato, so that, thiourea dominates over inhibiting effects of major sprout on minor ones in each eye, and neutralizes terminal buds capacity to stop lower buds growth in seeding tuber. 
Using thiourea treatment and/or applying $\mathrm{H}_{2} \mathrm{O}_{2}$ enable one to remove tubers dormancy (Bajji et al., 2007).

Thiourea $1 \%$ breaks dormancy, accelerated plants emergence, increased tuber number per plant, and leading to maximum yield in potato minitubers of Marfona cultivar (Germchi et al., 2011). Thiourea solution with $1 \%$ concentration for 1 hour in $25^{\circ} \mathrm{C}$ through sinking minitubersis better than other treatments (IAA and $\mathrm{GA}_{3}$ ) with fast germination and more sprouts. Microtubers treated with thio-urea induced the highest number of sprouts as compare to other treatments (Rehmanet al., 2001).The microtubers without insertion treated with $\mathrm{GA}_{3}$ and thiourea combination resulted complete (100\%) sprouting Ju et al. (2001).

Gibberllic acid and thiourea: $1500 \mathrm{ppm} \mathrm{GA}_{3}$ and $5 \%$ thiourea reduced the dormancy period by $50 \%$ in 'Agria' cultivar (Hassan-Panah et al., 2007). 5 ppm $\mathrm{GA}_{3}$ in combination with $1 \%$ thiourea is more efficient in increasing sprouts number and length than control in 5 varieties of normal tubers of potato (Kasrawi and Alfayyad 1989). $\mathrm{GA}_{3} 1 \mathrm{ppm}$ concentration and thiourea with $1 \%$ concentration increases the plant growth and decreases dormancy period significantly in comparison with other treatments (Pietkiewicz, 1983). Combination of $1 \mathrm{ppm}$ Gibberllic acid $+1 \%$ Thiourea for $30 \mathrm{~min}$ dip performed best for growth attributing parameters like emergence and plant height, No. of stems and compound leaves under Gwalior conditions of central India (Annual Report- CPRS, 2012 and Annual Report - CPRI, 2012). $\mathrm{GA}_{3} 1 \mathrm{ppm}+$ thiourea $1 \%$ with 30,45 and 60 minutes soaking of microtubers resulted better performance in terms of yield of microtubers at Gwalior and Ooty (Annual Report- CPRS, 2012 and Annual Report- CPRI, 2012).

Randite: Randite (a 7:3:1) by volume mixture containing ethylene cholohydrin, 1, 2- dichloroethe and corbontetracholoride) is effective in breaking microtuber dormancy (Kim et al., 1996, 1999). However the mutaginically, carcinogenically and high toxicity of randite components make this mixture unacceptable to routine use. Cultivar diamont took the least time for $50 \%$ of tubers to sprout followed by cultivar Atlantic and highest sprouting ratio in all cultivars when treated with randite. (Rehman et al., 2001).

Corbondisulphide $\left(\mathbf{C S}_{2}\right)$ : Treatment with $\mathrm{CS}_{2}$ effectively terminates dormancy and the resulting sprouts are short, thick, robust, and resistant to breakage (Salimi et al., 2010). In $\mathrm{CS}_{2}$ treated minitubers showed significantly shorter dormancy and better sprouting, higher number of sprouts and length/ minituber. Longer duration of $\mathrm{CS}_{2}$ treatment exhibited a stronger action on breaking dormancy and sprouting of potato minitubers than shorter treatments. Longer duration with higher concentration of $\mathrm{CS}_{2}$ led to formation of needle sprouts when post harvest application of carbon disulphide $\left(\mathrm{CS}_{2}\right)$ in various concentrations $(0,15,25$, $35,45$ and $55 \mathrm{ml} \mathrm{m}-3)$ and with different exposure duration (24, 48, 72 and $96 \mathrm{~h}$ ) along with two ages (freshly harvested and one week after harvest) and two weight classes (1.5 and $12 \mathrm{~g})$ of potato minitubers of cultivar marfona was done (Salimi et al., 2010).

\section{Conclusion}

Microtubers play an important role in seed production programme in relation to prolonged storage in limited space, distance transportation of millions of basic seed planting material, minimization of transportation cost in comparison to seed potato tuber. In spite of these facts, small size, lenticels bursting, driage/ shrinkage and limited number of eyes are the major constraints in micro-tuber based seed production programme which must be addressed under intensive research programme. Although this technology is being replaced by aeroponic based mini-tuber production. As far as storage is concern, $4^{0} \mathrm{C}$ is best and feasible method but it can be increased depending upon the requirement of dormancy breaking period before planting of microtubers. Microtuber size, storage containers and conditions are significant factor for determining the viability of the microtuber. Gibberrlic acid, thiourea and their combinations, randite and carbon disulfide plays important role in dormancy breaking.

\section{REFERENCES}

Bajji, M. Hamdi, M.M., Gastiny, F., Rojas-Beltran, J.A. and Jardin, P. (2007). Catalase inhibition accelerates dormancy release and sprouting in potato (Solanumtuberosum L.) tubers. Biotechnology Agronomy Social Environmental, 11 (2): 121-131

Benedetti, M., Bisognin, D.A., Segatto, F.B., Costa, L.C., Bendinelli, M.G. and Brackmann, A. (2005). Dormancy breaking of potato minitubers. Ciencia Rural, Santa Maria, 35:31-38

Bolandi, A.R., Hamidi, H. and Ghavidel, R.A. (2011). The effects of size and microtuber dormancy on production of potato minitubers. World Applied Science Journal, 13 (3): 502-506

Burton, W.G. (1968). Work at the ditton laboratory on the dormancy and sprouting of potatoes. American Potato Journal, 45: 1-11

Burton, W.G. (1978). Post-harvest behavior and storage of potatoes. In: T.H. Coaker (Ed.), Applied biology, Vol. III. Academic Press, London, pp. 86-228

Burton,W.G. (1989). The potato, 3rd edn. Harlow: Longman Scientific and Technical.

Bus, C.B., Haverkort, A.J., Struik, P.C. and Van Der Zaag,D.E. (1990). Influence of the rate of early characteristics at emergencePotato Research, 37: 315-322

CPRI, (2011). Annual report, Central Power Research Institute, $150-151$

CPRI, (2012). Annual report, Central Power Research Institute, 106-109

CPRS, (2012). Annual report, Central Potato Research Station, Gwalior, 43-47

Germchi, S., Behroozi, F.G. and Badri, S. (2011). Effect of thiourea on dormancy breaking and yield of potato (Solanumtuberosum L.) minitubers marfona cv. in 
greenhouse. 2011 .International Conference on Environmental and Agriculture Engineering IPCBEE vol.15 (2011) () (2011) IACSIT Press, Singapore.

Habib, A. (1999). Microtuberization and dormancy breaking in potato (SolanumtuberosumL.) M.Sc. thesis, department of plant science, McGill University, Montreal, Quebec, $67 \mathrm{p}$.

Harris, P.M. (1992). The potato crop: The scientific basisfor improvement (2nd ed.). Chapman and Hall, London, $730 \mathrm{pp}$.

Hassan-Panah, D., Shahryari, R., Shamel, A. and Fathi, L. (2007). Effects of urea and $\mathrm{GA}_{3}$ on dormancy breaking of Agria potato minitubers. Abstract in the $5^{\text {th }}$ Iranian Horticulture Science Congress, ShirazUniversity, $100 \mathrm{P}$.

Hassan-Panah, D., Yarnia, M. and Khorshidi-Benam, M.B. (2007). Effects of thiourea and $\mathrm{GA}_{3}$ on dormancy breaking of Agria potato mini-tubers. Journal of Agriculture Science, 4:81-94

Hosseini, M.B., Afshari, R.T. and Salimi, K. (2011). Breaking dormancy of potato minituberswith thiourea. Potato J., 38 (1): 9-12

Hossain, M.J. (2012). Potato microtuber: a prospective: production and dormancy breaking of potato microtuber. Lap Lambert Academic Publishing, Bangladesh, 308

Ju, Y.L., Gu, L., Wang, B.J., Jiang, L. andLuo, Z.M. (2001). Studies on dormancy breaking in virus-free potato minituber. Acta Agriculturae Boreali Sinica., 16 (4): 36-41

Kanwal, A., Ali, A. and Shoaib, K. (2006). In vitromicrotuberization of potato (Solanumtuberosum L.) cultivar Kuroda- Anew variety in Pakistan. International Journal of Agricultural and Biology, 8(3): 337-340

Kasrawi, M.A. and Alfayyad, M. (1989). Yield and quality of potatoes as influenced by breaking dormancy of tuber seed. Agril. Sci., 13:51-68

Kefi, S., Pavlista, A.D., Meagher, M.M. and Read, P.E. (2000). Invertase activity as affected by cytokinin like compounds during potato tuberizationin vitro. American Journal of Potato Research, 77:57-61

Khorshidi-Benam, M.B. and Hassan-Panah, D.(2008). GA affects dormancy of Agria potato mini-tubers. Journal of New Agricultural Sciences, 12: 11-20

Kim, H.S., Jeon, J.H., Choi, K.H., Joung, Y.H. and Joung, H. (1999). Effects of randite on breaking dormancy of microtubers. American Journal of Potato Research, 76: 5-6

Kim, S.Y., Jeong, J.K., Kim, J.K. andLim, M.S. (1996). Effect of chemical treatments for dormoancy breaking of in vitomicrotubers of Solnumtuberousum L. cultivar. Dejima.Journal of Korean Society of Horticulture Science, 37: 19-23

Lazányi, J., Mándi, M., Tóth, I.J. and Dobránszki, J. (1998). Potato breeding at the Research Centre of Debrecen Agricultural University, 4(2):105-109

Leclerc, Y., Donnelly, D.J., Coleman, W.K., King and R.R. (1995). Microtuber dormancy in three potato cultivars. American Potato Journal, 72 (4): 215-223

Lommen, W.J.M. (1993). Post-harvest characteristics of potato minitubers with different fresh weights and from different harvests. I. Dry-matter concentration and dormancy. Potato Research, 36: 265-272

Lommen, W.J.M. (1994). Effect of weight of potato minitubers on sprout growth, emergence and plant characteristics at emergence. Potato Research, 37(3):315-322
Mosley, A.R., Yilma, S. and Charlton, B.A. (2007). Production of pre- nuclear potato seed from meristem to minitubers. OregonStateUniversity, Potato Project, 1-19

Naik, P.S. and Sarkar, D. (1997). Influence of light-induced greening on storage of potato microtubers. BiologiaPlantarum, 39 (1): 31-34

Narong, A. (1988). Microtuber production of potato (Solanumtuberosum L.) in vitro. Kasetsart Univ., Bangkok. Thai National AGRIS Centre (Thailand) PO Box 1084 Bangkok, 10903

Otroshy, M. and Struik, P.C. (2006). Utilization of tissue culture techniques in a seed potato tuber production scheme. Ph.D. thesis, Wageningen University, Wageningen, the Netherlands, 264

Paet, C.N. (1996). Breaking dormancy of potato microtubers. ASPRAD [Asian Sweet potato and Potato Research and Development] (2): 18

Park, S.W., Jeon, J.H., Kim, H.S., Hong, S.J., Aswath, C. and Joung, H. (2009). Effect of size and quality of potato microtubers on quality of seed potatoes in the cultivar 'Superior'. Scientia Horticulturae, 120 (1): 127 $-129$

Pietkiewicz, E. (1983). Comparison of the efficiency of breaking tuber dormancy with some chemicals. BiuletynInstytutu Ziemniaka, Poland, 30: 17-28

Pruski, K., Astatkie, T., Duplessis P. and Struik, P.C. (2003) Manipulation of microtubers for direct field utilization in seed production, American Journal of Potato Research, 80: 173-181

Ranalli, P., Bizarri, I.M., Borghi, L. and Mari, M. (1994). Genotypic influence on in vitro induction, dormancy length, advancing age and agronomical performance of potato microtubers (Solanumtuberosum L.) Annals of Applied Biology, 125 (1):161-172

Ranali, P. (1997). Innovative propagation methods in seed tuber multiplication programmesPotato Research, 40: 439-453

Rastovski, A. and van Es, A. (1987). Storage of potatoes: post-harvest behavior, store design, storage practice, and handling. Centre for Agricultural Publishing and Documentation, Wageningen, 453

Rehman, F., Lee, S.K., Kim, H.S., Jeon, J.H., Park, J.Y. andJoung, J.H. (2001). Dormancy breaking and effect on tuber yield of potato subjected to various chemicals and growth regulators under greenhouse conditions. Online Journal of Biological Science, 1 (9): 818-820

Rehman, F., Lee, S.K., Khabir, A., Joung, H.V. and Yada, R.Y. (2003). Evaluation of various chemicals on dormancy breaking and subsequent effects on growth and yield in potato microtubers under greenhouse conditions. ActaHorticulturae, 619:375-381

Reust, W. (1986). EAPR working group: Physiological age of the potato. Potato Research, 29: 268-271

Roşu, R., Chiru, N. and Rolot, J.L. (2004). Researches on genotype influence on potato microtuberization, Anale, INCDCSZ, Vol. XXXI, Tipografia Phoenix Brasov, 120 $-129$

Salimi, K.H., Hosseini, M.B., Struik, P.C. and Afshari, R.T. (2010). Carbon disulphide promotes sprouting of potato minitubers. Australian Journal Crop Science ,4(3):163168

Salimi, K.H., Tavakkol A.R., Hosseini, M.B. and Struik, 
P.C. (2010). Effects of gibberellic acid and carbon disulphide on sprouting of potato minitubers. Scientia Horticulture, 124: 14-18

Sharma, A.K., Venkatasalam, E.P. and Kumar, V. (2012). Storability and sprouting behaviour of micro-tubers of some Indian potato cultivars. Potato Journal, 39 (1): 31 $-39$

Shekari, F., Benam, M.B.K. and Hassanpanah, G. (2010). Effect of GA3 on dormancy breaking of 'Marfona' potato mini-tubers under greenhouse conditions.Journal of Food, Agriculture \& Environment, 8 (3\& 4): 422 425

Sonnewald, U. (2001). Control of potato tuber sprouting. Trends Plant Sci., 6: 333-335

Struik, P.C. and Wiersema, S.G. (1999). Seed potato technology. WageningenPers, Wageningen, theNetherlands, 383

Struik, P.C., van der Putten, P.E.L., Caldiz, D.O. and Scholte, K. (2006). Response of stored potato seedtubers from contrasting cultivars to accumulated daydegrees. Crop Science, 46: 1156-1168

Struik, P.S. and Lommen, W.J. (1999). Improving the field performance of micro- and minitubers. Potato Research, 42: 559-568

Suttle, J.C. (2004). Physiological regulation of potato tuber dormancy. American Journal of Potato Research, $81: 253-262$

Tábori, K.M., Dobránszki, J. and Ferenczy, A. (2000). Posteffects of light conditions on dormancy of potato microtubers. Acta Agronomica Hungarica, (48) 2: 127-132

Van Hiele, F.J.H. (1961). Un-sprouted potato tubers treated with gibberellic acid $\left(\mathrm{GA}_{3}\right)$. European Potato Journal, 4: 26-39

Van Ittersum, M.K. and Struik, P.C. (1992). Relation between stolon and tuber characteristics and the duration of tuber dormancy in potato. Netherlands Journal of Agricultural Science, 40:159-177

Wiersema, S.G., Cabello, R. and Booth, R.H. (1987). Storage behavior and subsequent field performance of small seed potatoes. Tropical Science, 27: 105-112

Wiltshire, J.J.J. and Cobb, A.H. (1996). A review of the physiology of potato tuber dormancy. Annals of Applied Biology, 129: 553-569 